\title{
Socio-economic characteristics of dairy and non-dairy households of chars of Northern Bangladesh
}

\author{
MF Islam ${ }^{1 *}$, MGS Alam, FY Bari and BF Zohara1 \\ Department of Surgery and Obstetrics, Faculty of Veterinary Science, Bangladesh \\ Agricultural University, Mymensingh-2202, Bangladesh
}

\begin{abstract}
Dairy and non-dairy households in chars in northern Bangladesh were compared. About $35 \%$ of dairy households earned money by selling milk along with labour. Dairy households owned more land than the non-dairy group. More dairy households $(70 \%)$ had drinking water and $74 \%$ had sanitation facilities, while $49 \%$ and $44 \%$ non-dairy households had such facilities. The dairy households owned 3065 livestock, of which 946 were cattle; while non-dairy households owned 1915 livestock, including 17 cattle. Average daily income of each dairy household was 129 Taka (US\$ $1=$ Taka: 56.31), and for non-dairy household it was 109 Taka. Many dairy households had a bicycle $(\mathrm{n}=54)$, radio $(n=59)$ and cell phone $(n=211)$, but fewer in the non-dairy had a bicycle $(n=8)$ and cell phone $(\mathrm{n}=43)$. The livestock are living assets for the flood-prone households and source of daily income. (Bangl. vet. 2017. Vol. 34, No. 2, 52 - 60)
\end{abstract}

\section{Introduction}

Poverty and poor living standards are characteristic of low-lying flood-prone river islands (chars) of northern Bangladesh: about 32\% of ultra poor people live in chars (UNDP, 2014). Various development partners endeavour to improve the living standard by improving livestock, especially indigenous cattle, which are assets for the poor landless people, who are extremely vulnerable to flash floods (Hodson, 2006; Howes, 2006). Over 95\% of the households in the chars retained their cows after devastating floods, when all other household goods were destroyed or lost. They keep livestock as a daily income source. As in many other parts in country, limited information was available on the performance of dairying in the chars. The objective of this study was to compare the socio-economic status of dairy and non-dairy households in order to evaluate the role played by cattle. This information is important for policy makers and development agencies in Bangladesh.

Human capital may be the most important resource in chars (Brojo et al., 2006). Gender plays a significant role in the process of household livelihood strategies, although the female contribution goes unnoticed. Women can play a substantial role in the labour force. Their indigenous knowledge and practice of environmental management increases the coping capacity of communities in hazardous situations and thus contributes to their survival. In the char livelihoods, men and women are

\footnotetext{
1Department of Medicine, Surgery and Obstetrics, Faculty of Veterinary and Animals Science, Hajee Mohammad Danesh Science and Technology University, Dinajpur-5200, Bangladesh

*Corresponding author:- E-mail: farukvet@hstu.ac.bd
} 
involved in several income-generating activities. Usually the only available resources are land and human resources, where females are predominantly engaged in the household work such as cooking, cleaning, washing, child care, sweeping, collecting fuel for cooking, paddy husking and taking care of elderly family members. Char women are directly involved in and contribute to rearing livestock or catching fish in open water and generate cash income. On the other hand, men are directly involved in all kinds of field activities.

\section{Materials and Methods}

Sample survey methods were used to collect data from the households through semistructured interviews and direct observation. Demographic information was collected on the livelihoods and problems of char dwellers. Fieldwork was conducted between October 2009 and March 2010.

\section{Study area}

The study was carried out to analyze the livelihoods of dairy and non-dairy households of char dwellers in three neighbouring Upazila (Sub-district) near the Jamuna River system under the Sariakandi of Bogra, Islampur of Jamalpur and Belkuchi of Sirajganj districts in Northern Bangladesh. Those chars were selected because they are flood-prone and highly vulnerable. The char dwellers keep dairy cattle as living assets, and it was projected that co-operation would be high so that reliable data could be obtained. The three Upazilas were selected because they are very close to the Jamuna River system. The villages were in a remote char area, quite far from the nearest town. The areas are usually inundated 2 to 3 times a year and therefore highly insecure. Huge numbers of unemployed people live in this area. The villages are poor and deprived of electricity and accessible roads and lack support from the government.

\section{Selection of households}

A total of 200 households (100 Dairy and 100 Non-dairy) from each of three Upazilas were selected. So, a total of 300 Dairy and 300 Non-dairy household were surveyed.

\section{Survey design and data collection}

Survey data was collected using interviews with a pre-tested survey schedule containing pre-coded and open-ended questions. The questionnaire was constructed in English and translated into Bengali during face-to-face interviews. To ensure a comprehensive study, the researchers intended to collect information from every household. The demographical data such as family size (defined as the number of persons, working or not, in the family, age group and education level were collected, and various components were assessed visually. The sanitation facilities, drinking water source, land ownership, livestock composition, as well as self-declared cash income of the respondent were collected. In addition, the ownership of items such as bicycle, radio, television, cassette player, cell phone and solar plant were noted. 
During the data collection period, the respondents' houses were visited for interviewing. If respondents were not willing to be interviewed, they were omitted next time. The analysis was based on the wealth status of the households.

\section{Data management and analysis}

Data was entered into the computer, normally using MS Excel. Data entry software MS Access was employed for data arrangement, reorganization and using code. All the quantitative data was processed and analysed using Statistical Package for Social Sciences (SPSS) Windows 11.5.

\section{Results and Discussion}

Assets as defined by Carney (1998) include human, natural, social, financial and physical capital. Assets themselves may improve well-being and lead to a better livelihood.

\section{Identification of household type}

Households having at least one breeding cow or heifer were considered as dairy households and those keeping none were considered as non-dairy.

\section{Household well-being status}

Two categories of economic well-being were identified, according to the number of milking cows (World Bank, 2004). Well-being status was strongly linked with the occupation and income distribution.

Variables identified as important in distinguishing households were: family size, land ownership, livestock composition, ownership of the cows/heifers, sanitation, source of drinking water, electronic devices such as radio, television, cell phone and solar plant, education, loans, selling labour, housing material, rickshaw pulling, homestead garden, food security, agricultural production and share cropping. Two types of households were identified (Table 1a and 1b). In the two categories of household, well-being status was dissimilar notably (Table $1 \mathrm{a}$ and $1 \mathrm{~b}$ ). Well-being differentiation is essential in understanding poverty and vulnerability (Moser, 1998). Well-being is directly related to income sources and activities of the households and plays a significant role in the diversification of livelihood strategies (Ellis, 2000).

\section{Characteristics of the respondents}

These studies were conducted on 300 dairy and 300 non-dairy households from the villages of Sariakandi, Islampur and Belkuchi Upazilas. The total population was 1516 in dairy and and 1508 in non-dairy households. The characteristics of the households are in Table 2.

The heads of the dairy and non-dairy households did not differ significantly by sex, age, education level and family size. About half of respondents in both groups were males: most were aged 36 to 50 years and had no primary education. These 
observations imply that there was no significant association between involvement in dairying and these characteristics.

Table 1a: Well-being status defined according to the dwellers of different chars

\begin{tabular}{lccc}
\hline \multicolumn{1}{c|}{ Criteria } & Dairy household & Non-dairy household \\
\hline Homestead land ownership (decimal) & $>5-10$ decimal & No land or $<5$ decimal \\
Cultivable land ownership (decimal) & $>10-20$ decimal & No land or $<10$ decimal \\
Sanitation & Mostly & Very few \\
Source of drinking water & Mostly from tube-well & Very few from tube-well \\
Food security & Rice 2-3 times/day & Rice once or twice a day \\
& or more \\
Food scarcity & No & 6 months \\
Agric. product & 20-30 maund & None or negligible \\
Sharecropper & Mostly & Very few \\
Education & Illiterate/Primary level & Illiterate/can sign only \\
& or above & \\
\hline
\end{tabular}

${ }^{1}$ Maund = unit of weight $(1 \mathrm{maund}=40 \mathrm{~kg})$

Table 1b: Well-being status defined according to the dwellers of different chars

\begin{tabular}{lcc}
\hline \multicolumn{1}{c}{ Criteria } & Dairy household & Non-dairy household \\
\hline Fishing from open water & Occasionally & Yes/Occasionally \\
Cattle & $1-4$ & None \\
Sheep/Goat & None or 1-3 & None or 1 \\
Poultry & $5-10$ & None or 2-5 \\
Loan from NGO/Bank/Others & None or 1000-2000 TK* & $1000-2000 \mathrm{TK}$. \\
Electronic devices & Cell phone, Bicycle, Radio, & None/Cell phone \\
Selling labour & Television, Solar plant & or Bicycle \\
Housing material & No & Mostly \\
& Tin shed, Bamboo, Wood, & Straw, Bamboo, Jute \\
Rickshaw/Van pulling & Jute stick & Stick, Soil \\
Homestead garden & No & Yes \\
\hline
\end{tabular}

${ }^{*}$ Taka = Bangladeshi currency (1US $\$=56.31$ Taka during the period of data collection)

About 57 percent of household members are 36-50 years old, which means that their working capacity is strong and their skills are increasing (Table 2). About 29 percent of household heads in the study areas are more than 51 years old, which means that their working capacity is reduced and their skills are decreasing (Table 2). To take 
care of elderly people, the government provides an old age allowance by means of the VGF scheme.

About 87 percent of the sample households are functionally illiterate (Table 2). Adult education might be the best way of improving the education level so that household members could be encouraged to educate their next generation. The current generation is getting support from the government to attend school. Now primary education is free for all and education is free for all rural females up to higher secondary level.

Family size was an important determinant of living conditions and the welfare of family members. About 44 percent of households had more than six family members and 51 percent had 4 to 5 family members (Table 2). Only about 5 percent had 1 to 3 family members. The mean household size (4.6 family members) is similar to the household size in the national census data 2001, which was 4.9 (BBS, 2004). The dairy group tended to have more medium and large families than the non-dairy group.

The composition of a household changes constantly due to factors such as gender, age, marital status, family size etc. and it encompasses labour, income capacity and household relations (Ellis, 2000, Moser, 1998).

Table 2: Characteristics of respondents

\begin{tabular}{|c|c|c|c|c|}
\hline \multirow[t]{2}{*}{ Variables } & \multicolumn{2}{|c|}{ Household } & \multirow{2}{*}{$\begin{array}{c}\text { Total } \\
(n=600)\end{array}$} & \multirow[t]{2}{*}{$x^{2}$-value } \\
\hline & Dairy $(\mathrm{n}=300)$ & Non-dairy $(\mathrm{n}=300)$ & & \\
\hline \multicolumn{5}{|l|}{ Sex: } \\
\hline Male & $51.6 \%$ & $49.9 \%$ & $50.7 \%$ & \multirow{2}{*}{0.05} \\
\hline Female & $48.4 \%$ & $0.1 \%$ & $49.3 \%$ & \\
\hline \multicolumn{5}{|l|}{ Age (in year): } \\
\hline$<35$ & $13.2 \%$ & $13.3 \%$ & $13.2 \%$ & \multirow{3}{*}{0.04} \\
\hline $36-50$ & $55.3 \%$ & $60.0 \%$ & $57.4 \%$ & \\
\hline $51+$ & $31.6 \%$ & $26.7 \%$ & $29.4 \%$ & \\
\hline \multicolumn{5}{|l|}{ Educational level: } \\
\hline No formal education & $86.2 \%$ & $88.2 \%$ & $87.2 \%$ & \multirow{4}{*}{0.04} \\
\hline Primary education & $11.5 \%$ & $11.3 \%$ & $11.3 \%$ & \\
\hline Secondary education & $1.8 \%$ & $0.5 \%$ & $1.2 \%$ & \\
\hline College and above & $0.5 \%$ & $0.0 \%$ & $0.3 \%$ & \\
\hline \multicolumn{5}{|l|}{ Family size: } \\
\hline Small $(\leq 3)$ & $50.0 \%$ & $50.0 \%$ & $5.1 \%$ & \multirow{3}{*}{0.85} \\
\hline Medium (4-5) & $51.7 \%$ & $48.3 \%$ & $51.3 \%$ & \\
\hline Large $(>6)$ & $56.9 \%$ & $43.1 \%$ & $43.6 \%$ & \\
\hline
\end{tabular}

Dairy and non-dairy households did not differ significantly 
Table 3 depicts information about the primary occupations of the respondents. Five categories were formed. Almost 47 per cent of respondents were selling labour. But in dairy group about 35 per cent of household earning was by selling milk along with labour, and only two per cent of households were fully involved with milk selling.

In dairy and non-dairy households one occupation is not enough to cover their expenses. At certain periods of the year, they cannot find work. The secondary occupation is more diversified and labour-intensive. When hardship and crisis occur, some household members migrate to nearby towns to work (Brojo et al., 2006).

Table 3: Distribution of household according to different income source

\begin{tabular}{l|cc|c|c}
\hline \multirow{2}{*}{ Income source } & \multicolumn{2}{|c|}{ Household } & Total & \multirow{2}{*}{$\chi^{2}$-value } \\
\cline { 2 - 3 }$(\mathrm{n}=117)$ & \\
\hline Milk sales & Dairy $(\mathrm{n}=54)$ & Non-dairy $(\mathrm{n}=63)$ & \\
Labour & $2(100 \%)$ & $0(0.0 \%)$ & $2(1.70 \%)$ & 0.15 \\
Fishing & $11(23.4 \%)$ & $36(76.6 \%)$ & $47(40.2 \%)$ & 0.12 \\
Milk sales + Labour & $0(0.0 \%)$ & $1(100 \%)$ & $1(0.9 \%)$ & 0.15 \\
Labour + Fishing & $35(100)$ & $0(0.0 \%)$ & $35(29.9 \%)$ & 0.15 \\
\hline
\end{tabular}

Dairy and non-dairy households did not differ significantly

The most important capital in chars is land, water and livestock. It may be useful to think of natural capital as occurring in a gradient between low and high agroecological potential for livelihood analysis (Ellis, 2000; Carney, 1998; Scoones, 1998). Land ownership is an important factor in maintaining a livelihood strategy. Most of the dairy group had at least 5 or 10 decimals $\left(1\right.$ Decimal $\left.=40.5 \mathrm{~m}^{2}\right)$ of land, and around $40 \%$ had $10 \mathrm{dl}$ of cultivable land. But in the non-dairy group, the land ownership was lower, only a quarter to one third owning $5 \mathrm{dl}$ of land (Table 4).

Almost all the sample households are functionally landless (Fig. 1). Subsequently their livelihoods are vulnerable, because the income from land resources is not enough to cover costs.

The 300 dairy households had 946 cattle, 845 sheep and goats, 1271 birds and 3 horses. The non-dairy households possessed 17 cattle, 766 sheep and goats, and 1132 birds. The majority of livestock-keepers (74\%) owned 2 or 3 dairy cattle (Table 5). Livestock resources can potentially contribute to recovering from the aftermath of flooding. During this time, most households sell their livestock to cover daily expenses. Livestock resources play an important role as fixed assets.

Table 6 shows that dairy households had significantly $(\mathrm{P}<0.05)$ better sanitation and drinking water facilities than the non-dairy households. It is interesting to note that almost 70 per cent of dairy and 49 percents of non-dairy households use tube wells for safe drinking water but 30 percent of dairy and 51 percent of non-dairy do not own a 
tube well as source of safe drinking water. It is distressing to note that only 74 and 44 per cent of dairy and non-dairy households have toilet facility. They use any free place as a toilet. This is the main cause of disease in the flood season.

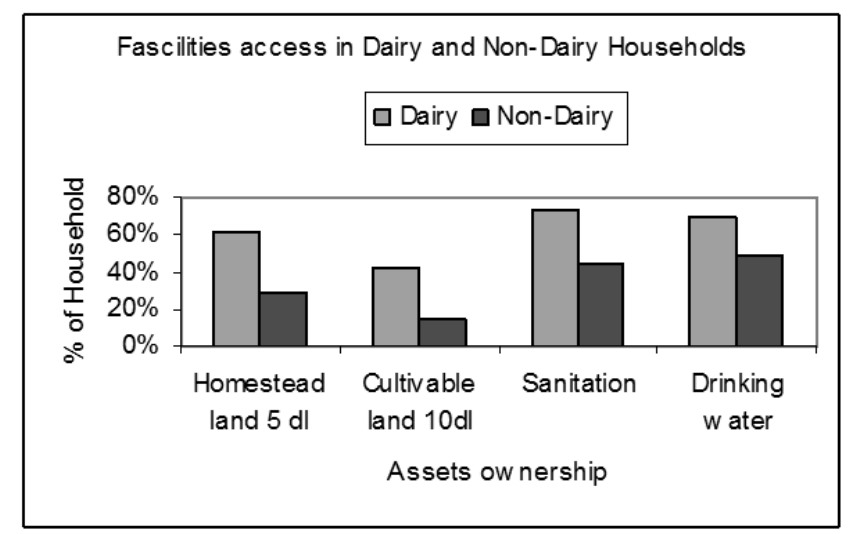

Fig. 1: Facilities access by two type household

Table 4: Land ownership (\% of households) among the dairy and non-dairy households

\begin{tabular}{lcc|cc|c|c|c|c}
\hline \multirow{2}{*}{ Particulars } & \multicolumn{6}{c}{ Households } \\
\cline { 3 - 9 } & & \multicolumn{3}{|c}{ Dairy } & \multicolumn{4}{c}{ Non-dairy } \\
\cline { 3 - 9 } & & S & I & B & S & I & B \\
\hline Land & Homestead & $5 \mathrm{dl}$ & 61 & 62 & 60 & 34 & 26 & 27 \\
ownership & $\left({ }^{*} \mathrm{dl}\right)$ & $10 \mathrm{dl}$ & 14 & 10 & 13 & 4.5 & 2.5 & 2.5 \\
& Cultivable & $10 \mathrm{dl}$ & 44.5 & 43.5 & 38 & 15.5 & 15 & 14 \\
& $\left({ }^{*} \mathrm{dl}\right)$ & $20 \mathrm{dl}$ & 13.5 & 12 & 15 & 0 & 0 & 0 \\
\hline
\end{tabular}

*dl = decimal, $1 \mathrm{dl}=405 \mathrm{~m}^{2}, \mathrm{~S}=$ Sariakandi, $\mathrm{I}=$ Islampur, $\mathrm{B}=$ Belkuch

Table 5: Distribution of households by number of dairy animals owned

\begin{tabular}{lcc}
\hline \multicolumn{1}{c}{ No. of dairy cattle } & Frequency $(\mathrm{n}=300)$ & Percent $(\%)$ \\
\hline 1 & 57 & 19 \\
2 & 138 & 46 \\
3 & 84 & 28 \\
$>3$ & 21 & 7 \\
\hline
\end{tabular}

The dairy household group had a significantly $(\mathrm{P}<0.05)$ higher average daily income. Average self-declared daily cash income of each dairy household was Taka $129 \pm 11.2$ (1 US \$ = Taka: 72). But Taka $109 \pm 15.7$ was the sole income for the non-dairy group (Table 7). 
Table 6: Distribution of households by ownership of Sanitary Latrine and Tube-well

\begin{tabular}{l|c|c|c|c}
\hline \multirow{2}{*}{ Variables } & \multicolumn{2}{|c|}{ Household } & Total & $\chi^{2}$-value \\
\cline { 2 - 3 } & $\begin{array}{c}\text { Dairy } \\
(\mathrm{n}=300) \%\end{array}$ & $\begin{array}{c}\text { Non-dairy } \\
(\mathrm{n}=300) \%\end{array}$ & & \\
\hline Sanitation (Sanitary latrine): & 74 & 44 & 59 & $55.8^{*}$ \\
Available & 26 & 56 & 41 & \\
Not available & & & & \\
\hline Drinking water source (Tube well): & 70 & 49 & 59.5 & $27.45^{*}$ \\
Available & 30 & 51 & 40.5 & \\
Not available & & &
\end{tabular}

*= Significant at $(\mathrm{P}<0.05)$

Livestock is an important component of financial capital which acts as a buffer in bad times (Ellis, 2000).

Table 7: Average daily household income (in Taka) of Dairy and Non-dairy groups

\begin{tabular}{c|c|c|c|c}
\hline Variable & $\begin{array}{c}\text { Dairy farmers } \\
(\text { Mean } \pm \text { S.D })\end{array}$ & $\begin{array}{c}\text { Non-dairy farmers } \\
(\text { Mean } \pm \text { S.D })\end{array}$ & Difference & $t$-value \\
\hline Household income (Taka/day) & $129 \pm 11.2$ & $109 \pm 15.7$ & 20 & $1.8^{*}$ \\
\hline
\end{tabular}

S.D = Standard deviation; ${ }^{*}=$ Significant at $(\mathrm{P}<0.05)$

The dairy households had more household items: a bicycle $(n=54)$, radio $(n=59)$ and cell phone $(n=211)$, but fewer in non-dairy group enjoyed a bicycle $(n=8)$ and cell phone $(n=43)$. Household assets such as radios, cassette players and televisions play a significant role in getting access to news, recreation, the weather forecast, agricultural information and markets, but very few of the households have such assets. Bicycles can assist communication and transport and sometimes are used for carrying goods. This char area is served by a cell phone network, so people can contact buyers, who then come to the chars to purchase agricultural products. Households are extremely vulnerable to external risk and unanticipated income failure, especially natural calamities (Ellis, 2000).

\section{Conclusions}

The chars are particularly vulnerable to the effects of flooding, drought and cyclones, which increase the precariousness of poor people's lives by wiping out assets and pushing them deeper into poverty. Dairy rearing in chars contributed a lot to the household welfare in terms of household assets, sanitation, safe drinking water, and income. So, dairying can enhance the living standards of the char dwellers. 


\section{References}

BBS 2004: Statistical Pocket Book of Bangladesh. Bangladesh Bureau of Statistics, Statistical Division, Ministry of Planning, Government of People's Republic of Bangladesh, Dhaka, Bangladesh.

Brojo Gopal P 200: Household livelihoods analysis of char dwellers using the capital asset framework: the case of NRSP area, Jamalpur, Bangladesh. MSc Thesis in International Studies in Aquatic Tropical Ecology, Faculty for Biology and Chemistry, University of Bremen, Germany.

Carney D (ed) 1998: Sustainable Rural Livelihoods: What contribution can we make? Papers presented at the Department for International Development's (DFID), National Resources Advisers' Conference, July 1998, London, United Kingdom.

Ellis F 2000: Rural Livelihoods and diversity in developing countries. Oxford University Press, Oxford, United Kingdom.

Hodson R 2006: The Char Livelihood Programme: The Story and Strategy So Far. CLP Secretariat, RDA campus, Bogra, Bangladesh.

Howes M 2006: An introduction to the Char Livelihood Programme (mick.howes1 ${ }^{\circledR}$ ntlworld.com). CLP Secretariat, RDA campus, Bogra, Bangladesh.

Moser C 1998: "The Asset Vulnerability Framework" Reassessing Urban Poverty Reduction Strategies. World Development 2619.

Scoones I 1998: Sustainable rural livelihoods: A framework for analysis. IDS working paper 72 .

UNDP 2014: Human Development Report 2013/2014: United Nations Development Programme, New York, United State of America.

World Bank 2004: The World Bank Group-Millennium development goals. United Nations Millennium Goals, World Bank. Retrieved at 4 May, 2006 from www.development goals.org/index.html. 